\title{
sciendo
}

CIVIL AND ENVIRONMENTAL ENGINEERING REPORTS

E-ISSN 2450-8594

CEER 2021; 31 (1): 0044-0053

DOI: 10.2478/ceer-2021-0003

Original Research Article

\section{CHARACTERISTIC FEATURES OF HYBRID BRIDGE STRUCTURE MODELS}

\author{
Czesław MACHELSKI ${ }^{1}$ \\ Faculty of Civil Engineering of the Wroclaw University of Technology
}

\begin{abstract}
This work discusses the classification of bridge structures and their models. Examples of hybrid models are also indicated in the case of homogeneous and mixed structures. Where hybrid design and model cases are presented, an algorithm for the analysis of contact interactions between subsystems is provided. The soil and shell structure is adopted as an example of analyses, where in its characteristic feature, differentiating it from classic bridges, is the large influence of both the soil backfill and the road surface as load-bearing elements of the structure. There are two structural subsystems present in the model of the soil-shell structure: a corrugated sheet coating and a soil backfill with a surface. The interaction between them is modeled as a contact interaction, i.e. forces with a direction normal and tangent to the line of the circumferential band of the shell. The paper presents an algorithm of their analysis, resulting from the outcomes of tests with the use of strain gauges, with the load being a vehicle changing its position. The advantage of the algorithm is that it takes into account the actual physical properties of the soil in the backfill layers and the contact layer of the coating with the soil. Direct contact force measurements along the entire length of the circumferential strip are very difficult. In practice, pressure gauges are used to determine normal interactions.
\end{abstract}

Keywords: soil-steel bridge, models of hybrid structures, contact forces, investigation

\footnotetext{
${ }^{1}$ Czesław Machelski: University of Technology Wroclaw, czeslaw.machelski@pwr.edu.pl, phone: 600129725
} 


\section{HYBRID BRIDGE STRUCTURES}

According to the Dictionary of Foreign Words, a hybrid is an object that is made up of different elements that do not fit together. In the biological definition, this means the crossing of two genetically different specimens, resulting in a hybrid. In the automotive industry, a hybrid is a car powered by two different engines, for example electric and internal combustion. Thus, a bridge as a whole - with the span, pillars and abutments - is a construction hybrid. Each of its components: the span as a bending beam, the intermediate support as a compression element, and the abutment as a retaining wall, are completely different elements of the same bridge.

From the above definitions, it follows that it is a mixed structure of a suspended bridge (as in Fig. 1) and a hanging bridge, as systems consisting of various elements: band, beam, and pillar. In this case, the performance characteristics of the elements, and not the variety of materials, are taken as the basis for classification [11]. Composite structures $[5,10]$ can be classified as mixed systems due to the materials used in the construction of the bridge girders.

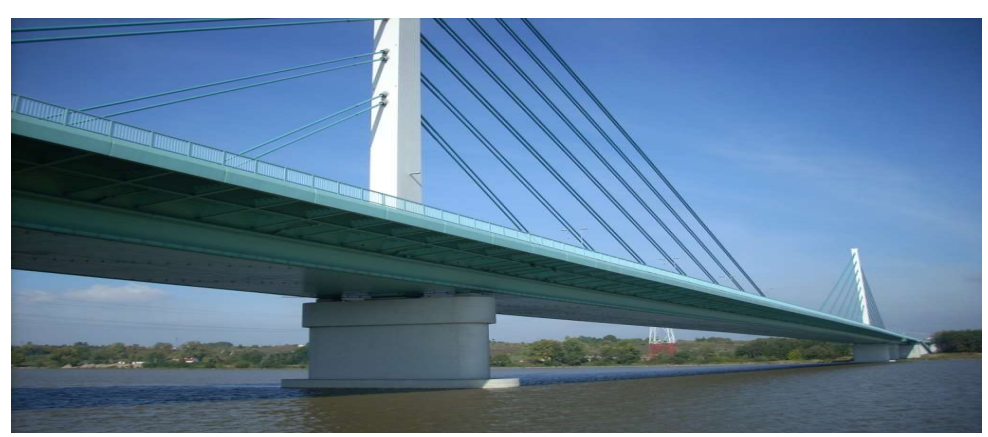

Fig. 1. View of a bridge with suspended system in Płock

A characteristic feature of the hybrid bridge model is the division of the structure into subsystems $[1,2]$. The computational model of the object applies the condition of interaction of subsystems as force reciprocity or (and) compliance of displacements. A special group consists of integrated bridge structures [4] as hybrid structures. This type of bridge structure may be made of a homogeneous material, e.g. concrete, but the homogeneous structure of the bridge cooperates in the model with the ground as the second subsystem.

Table 1 shows examples of dependencies of the constructions to their models in beam type girders. The analyzed group distinguishes bridge spans of uniform structure, e.g. concrete or mixed, e.g. composite and hybrid. Regardless of the design, there may be various models, e.g. with a homogeneous structure but hybrid model [2]. Examples of models of such spans are discussed below. 
Table 1. Schemes of span structures and their models

\begin{tabular}{|c|c|l|c|c|}
\hline \multirow{2}{*}{ CONSTRUCTION } & homogenous & \multirow{2}{*}{$\begin{array}{c}\text { homogene- } \\
\text { ous }\end{array}$} & \multirow{2}{*}{ MODEL } \\
& mixed & & mixed & \\
\cline { 2 - 2 } & hybrid & & hybrid & \\
& & &
\end{tabular}

\section{HOMOGENEOUS CONSTRUCTION SPANS}

Simple homogeneous models are also used in the spans of bridges made of homogeneous material. Examples of such geometry of spans made of precast concrete beams are shown in Table 2.

Table 2. Examples of span models made of homogeneous material (concrete)

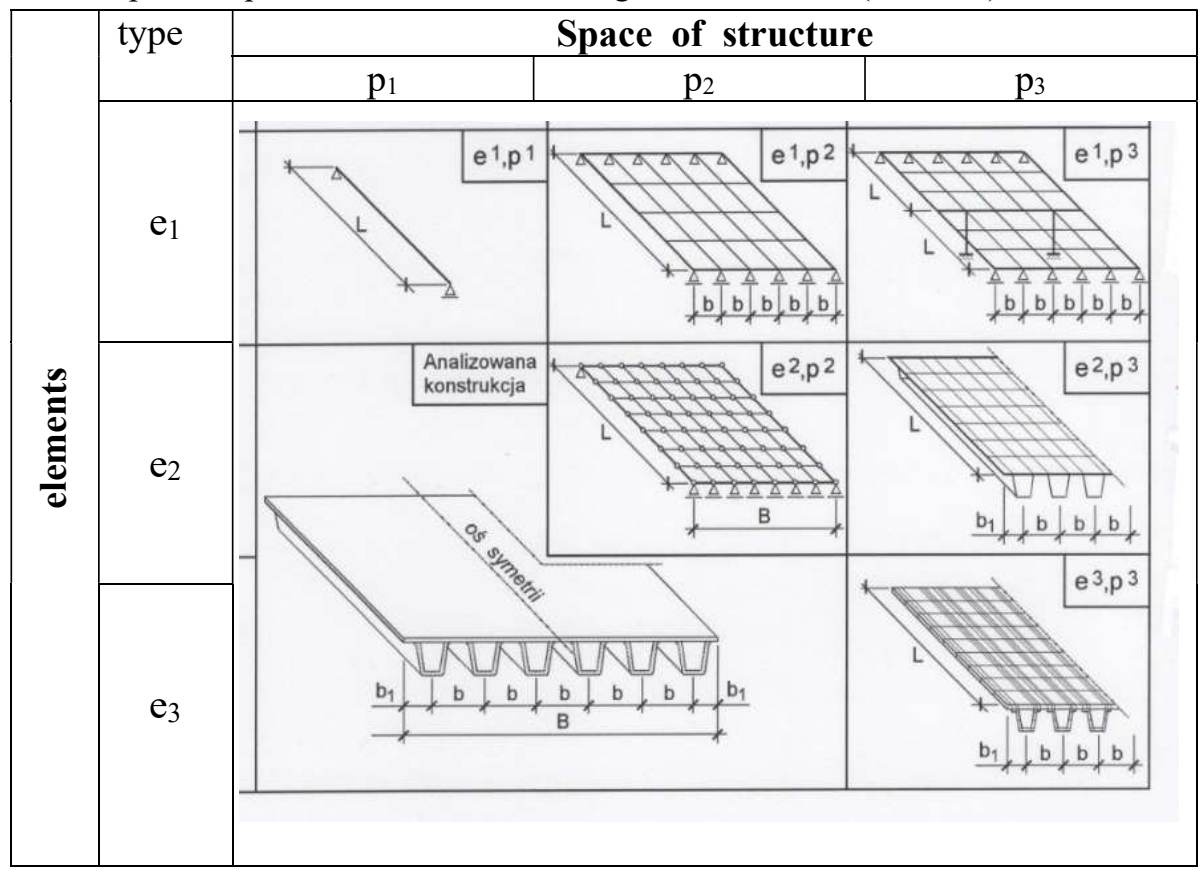

Symbol $e^{\mathrm{i}}$ is used to define the type of element and $p^{\mathrm{i}}$ as a bridge geometry space, respectively. Thus, the model of a span made of trough beams, as shown in the drawing in Table 2, may be a bar system $e^{1}$, as: beam (with previously used load distribution $p^{1}$ ); flat grate $p^{2}$; or a beam grate supported on pillars forming a spatial frame scheme $p^{3}$. When using $e^{2}$ surface elements, a $p^{2}$ orthotropic plate, or a 
ribbed-plate structure, a $p^{3}$ system is obtained. A model that uses volumetric elements $\left(e^{3}, p^{3}\right)$ takes a special place.

\section{MIXED CONSTRUCTION SPANS}

In the case of a bridge made of steel encased beams, i.e. a mixed structure (due to the material), a homogeneous model in the form of an orthotropic plate $\left(e^{2}, p^{2}\right)$ is applied. Also, in a composite bridge with a plate girder structure with a concrete bridge deck, the homogeneous model can be used as a flat grating $\left(e^{1}, p^{2}\right)$. In this case, the beam elements made of various materials in the span are reduced to a homogeneous material, e.g. concrete or steel. In the same structure example, one may also use a model with mixed elements $\left(e^{1}+e^{2}, p^{3}\right)$ (steel plate girders as bar ribs $e^{1}$ with a concrete bridge deck $e^{2}$ ).
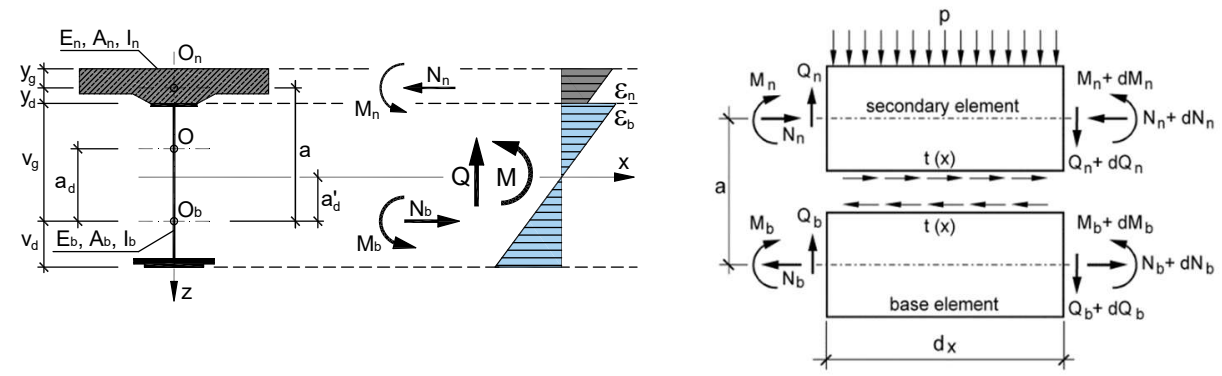

Fig. 2. Model of a composite beam with a flexible joint

In the case of a span made of trough beams, as shown in the figure in Table 2, but made of different materials [11, 12], it may take the following models:

- rod layout $\left(e^{1}, p^{1}\right)$ as a beam (using lateral load distribution);

- flat grate $\left(e^{1}, p^{2} ;\right)$ with the main girders and the catwalk as beams;

- orthotropic plate $\left(e^{2}, p^{2}\right)$ when the elements are reduced to a uniform material;

- plate-disc system $\left(\mathrm{e}^{2}, p^{3}\right)$ with various elements of the material of the plate and beams.

Figure 2 shows an example of a composite beam in the form of a plate girder with a concrete bridge deck, but in a hybrid model. To connect both materials, a flexible connection was used, e.g. bolt or glue $[5,10]$. The interaction of both subsystems [6] are tangential forces $t$, as shown in fig. 2. In this case, the horizontal displacements ( $\varepsilon$ deformations) in the joint do not correspond. The condition of compliance of deflections and curves in bar subsystems reduced to two axes of inertia is applied. 


\section{HYBRID CONSTRUCTION OBJECTS}

In the case of the hybrid model, as presented in Fig. 2, there are flexible connectors between the subsystems. In the hybrid construction, as presented in Fig. 3, a specially modeled contact layer is used between the subsystems. An example of an engineering soil and shell structure is distinguished by a particularly heterogeneous layered structure.

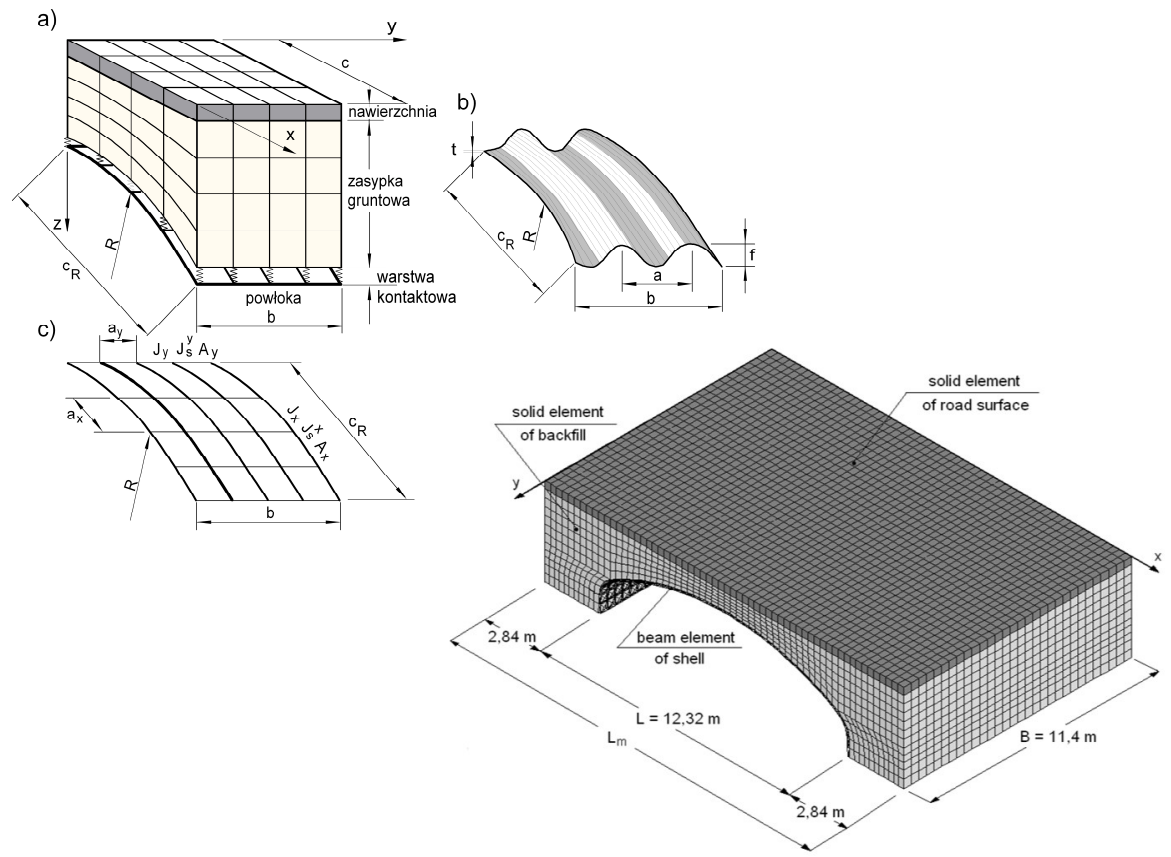

Fig. 3. Model of the bridge soil and shell structure [7]

Their characteristic feature, unlike classic bridges, is the adoption of backfill as the basic material of the structure. The influence of the road surface as load-bearing elements is significant [7]. Of particular importance in this model is the mapping of the contact layer between the soil backfill and the steel interface, as shown in Fig. 3 - analyzed in this paper.

The paper defines the principles of soil influence on the surface with the use of the object test results [8]. A strain gauge base is used for measurements. Tensometric strain gauges are glued on to the corrugated sheet surface accessible from the inside, on the selected circumferential band of the surface. In each measurement cross-section, the sensors were placed in pairs, in the apex and depression of 
the corrosion, located in the direction of the circumferential strip of the surface, as in Fig. 4.

The twin alignment of sensors, using the principle of flat cross-sections, allows determining the deformations in the axis of inertia of the cross-section of the corrugated sheet and thus to determine the peripheral axial force from the dependence

$$
n(s)=\frac{E A}{a} \frac{\varepsilon_{D}(f-g)+\varepsilon_{g}(f+g)}{2 f} .
$$

Formula (4.1) includes the geometry of the corrugated sheet, e.g. SC $a \times f \times g$ (wave length $a$ its height $f$ and sheet thickness $g$ ). To determine the change in curvature $\kappa$ and the shell curvature radius $\rho$, the geometric relations of the plate and $\varepsilon_{D}$ and $\varepsilon_{g}$ can be used, and thereby find the bending moment as in the equation

$$
m(s)=\frac{E I}{a} \frac{\varepsilon_{g}-\varepsilon_{D}}{f},
$$

where: $A / a=9.81 \mathrm{~mm}^{2} / \mathrm{mm}$ and $I / a=24165 \mathrm{~mm}^{4} / \mathrm{mm}$ are the geometrical characteristics of the cross-section of the corrugated sheet SC $381 \times 140 \times 7$ while $E=$ $205 \mathrm{GPa}$ is the strength property of the material (steel).

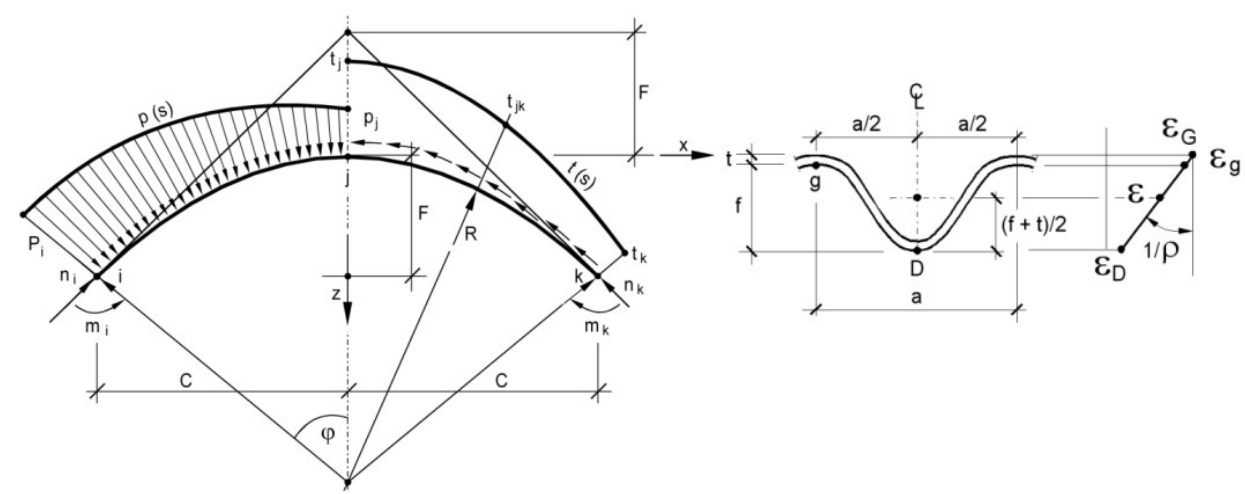

Fig. 4. Internal forces and soil influences on the surface

From the function of internal forces $n(s)$ and $m(s)$ the normal interactions distributed along the circumferential band of the surface can be obtained as $s$

$$
p(s)=\frac{d^{2} m}{d s^{2}}+\frac{n}{R}
$$

and tangents interactions 


$$
t(s)=\frac{d n}{d s}+\frac{d m}{d s} \frac{1}{R} .
$$

Identification of the function $p(\mathrm{~s})$ and $t(\mathrm{~s})$ enables a separate analysis of the surface as subsystems separated from the structure: the circumferential band and the backfill, as in Fig. 3. This general solution full fills the static condition of the compliance of the contact actions between the soil and the surface. The principle of displacement compliance is not taken into account, i.e. a slip is allowed at the joint of the subsystems, as in the composite beam shown in Fig. 2. This is an important advantage of this algorithm - in line with the principle of the structure's work.

\section{THE EFFECTS OF WORK OF HYBRID STRUCTURE}

As an example of the research on contact interactions, the work presents the results of measurements of a test structure built in Rydzyna, with a record span $L$. = $17.594 \mathrm{~m}$ of sheet metal SC $381 \times 140 \times 7$ [8]. The geometrical parameters of the circumferential band of the shell related to the axis of inertia of the corrugated sheet in the object are: height $H .=5.459 \mathrm{~m}$ and the radius of curvature at the crown $R=13.735 \mathrm{~m}$. The thickness of the backfill above the surface was $h_{n}=1.12$ $\mathrm{m}$.

The test used a loader changing its position along the circumferential band of the surface. The position of the vehicle on the object was defined as a coordinate relative to the shell crown $x_{\mathrm{p}}$. The loader traveled in an incremental manner of $\Delta x_{p}=$ $1.5 \mathrm{~m}$. The axle loads in the loader (without load) were similar: $P_{1}=114.3 \mathrm{kN}$ (reference axis) and $P_{2}=104.7 \mathrm{kN}$. The wheel base was $3.4 \mathrm{~m}$. The position of the vehicle wheels was symmetrical in relation to the analyzed surface measurement line.

Figures 5 and 6 show changes in contact interactions as a normal force $p\left(\mathrm{x}_{\mathrm{p}}\right)$ and the tangent $\left(\mathrm{x}_{\mathrm{p}}\right)$ at the midpoint of the surface (crown). The value is given on the horizontal axis of these graphs $x_{\mathrm{p}}$ as a force distance $P_{1}$ from the surface crown as the first axis loading the structure.

The figure legend marks the graph created during the primary travel and the secondary travel (return). During both runs, the vehicle position marked as $x_{\mathrm{p}}$ was identical. The specific vehicle positions are:

- $x_{\mathrm{p}}<L / 4=4.4 \mathrm{~m}$ where there is an increase in contact interactions;

- $x_{\mathrm{p}}=0$ when axis $P_{1}$ of the loader is located above the crown;

- $x_{\mathrm{p}}=-1.7 \mathrm{~m}$ when axles $P_{1}$ and $P_{2}$ of the vehicle are equidistant from the crown;

- $x_{\mathrm{p}}=-3.4 \mathrm{~m}$ when axis $P_{2}$ is above the crown.

The start and end of the measurements took place when $x_{\mathrm{p}}=21 \mathrm{~m}$. When $x_{\mathrm{p}}=-9$ $\mathrm{m}$, the direction of travel was changed without the vehicle turning. 


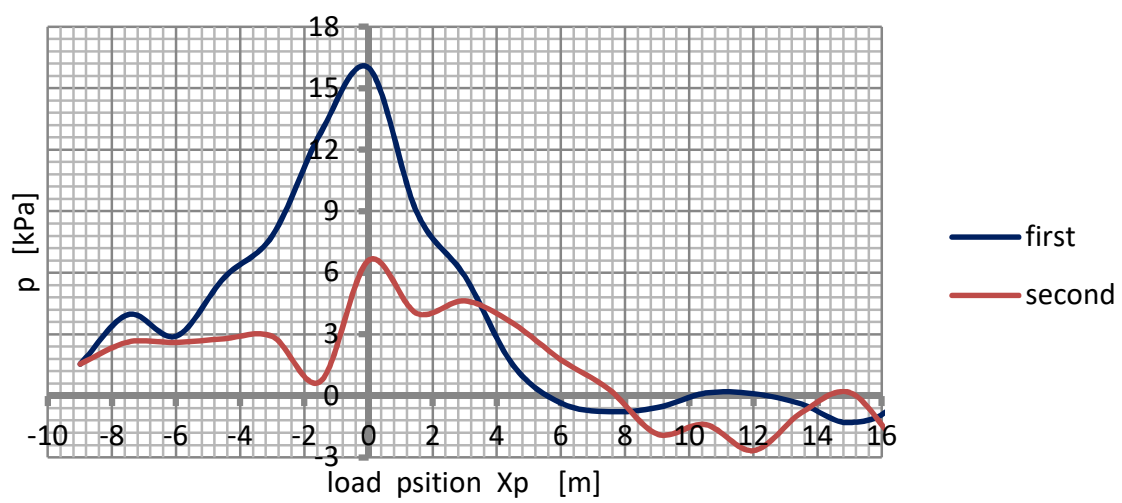

Fig. 5. Change in soil normal action on the surface crown

During the primary and secondary travel, the diagrams in Figures 5 and 6 are different, in particular when the vehicle is in the area of the shell crown. There is a very significant difference in the value of soil pressure. During the primary travel, there is no second wave with an extreme value $p\left(\mathrm{x}_{\mathrm{p}}\right)$ when $x_{\mathrm{p}}=-3.4 \mathrm{~m}$, i.e. when the second axle of the loader is above the analyzed point $P_{2}$. Such extremes are visible on the secondary travel.

Figure 6 shows the diagrams of tangential interactions $t$ in the shell crown. Maximum values $t$ are greater than $p$, but this only applies to the vehicle loading effect and not to the cumulative effects with the weight of the backfill. The essential difference $t$ with regard to pressure $p$ is that, during the primary and secondary travel, functions $t\left(\mathrm{x}_{\mathrm{p}}\right)$ are very similar. It is important to reduce the impact $p$ and $t$ when the vehicle returns to its initial state. Thus, the impact of the soil on the surface disappears after the vehicle exits, so there is a return to the initial state and a hysteresis loop [13]. 


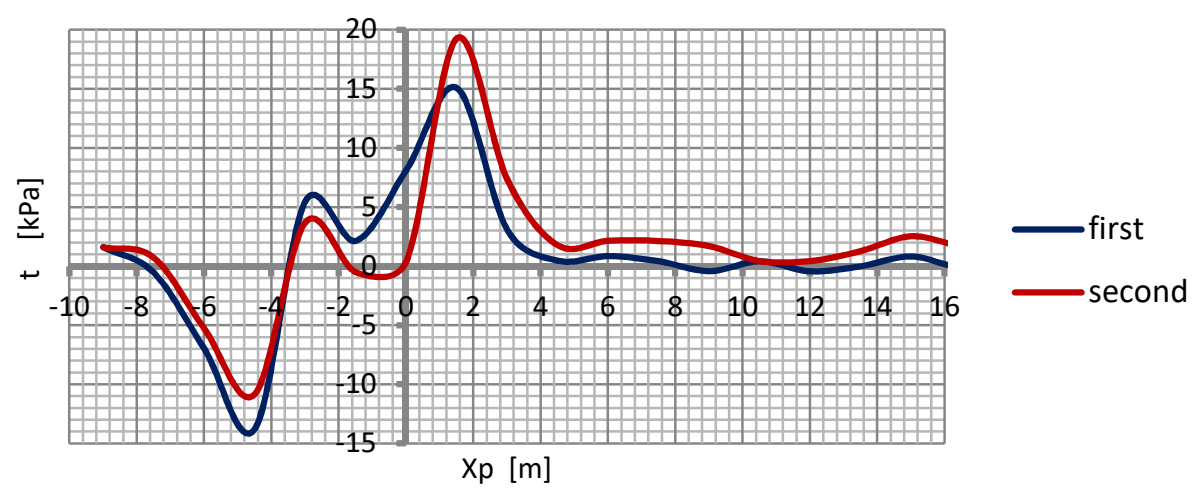

Fig. 6. Tangential effects of soil on the circumferential band of the coating

\section{SUMMARY}

The paper discusses the classification of bridge structures and their models of the geometry of the supporting system. The use of hybrid models was also indicated in the case of homogeneous and mixed structures. The contact interactions between subsystems were analyzed using the example of a hybrid structure and a hybrid model used in the soil-steel structure.

The algorithm presented in the work, used for determining normal components $p$ and tangents $t$ was based on the results of strain gauge measurements on the structure. This type of research methodology allows obtaining data that are difficult to obtain in direct research. Ground pressures $p$ can be determined using pressure gauges. However, the determination of tangential forces along the length of the circumferential band is very difficult. This is due to the displacement inconsistency, i.e. the formation of a slip in the contact of subsystems. The example of the results given in the paper demonstrates a significant improvement in the observation of contact forces.

A characteristic feature of the construction example and the hybrid soil-steel structure model is the significant difference of displacements, internal forces, and contact actions (as demonstrated in the paper) during the primary and secondary (return) travels [9]. When the analyzed quantities return to their initial state after the vehicle has passed, a characteristic hysteresis loop appears [13]. This phenomenon in bridge structures is poorly recognized and concerns moving loads, with changing position $[3,6,9,10]$. 


\section{REFERENCES}

1. Bień, J and Machelski, C 1978. Hybrydowy sposób analizy statycznej konstrukcji pryzmatycznych. Konf. Problemy badawcze w inżynierii lądowej. Wrocław, 28-30 września, 5-14.

2. Bień, J, Kmita, J and Machelski, C 1987. Analiza statyczna układów płytowożebrowych z wykorzystaniem podziału na podukłady. Archiwum Inżynierii Lądowej. t. 33 z. 1 s. 23-52.

3. Chróścielewski, J, Miśkiewicz, M, Pyrzowski, Ł, Sobczyk, B and Wilde, K 2018. Badania odbiorowe obiektu gruntowo-powłokowego rekordowej rozpiętości. Mosty Nr 2 s. 52-54.

4. Furtak, K and Wrana, B 2005. Mosty zintegrowane. Wydawnictwo Komunikacji i Łączności, Warszawa.

5. Kuczma, B, Biliński, T and Kuczma, M 2011. Badania laboratoryjne połaczeń klejowych fragmentów zespolonych stalowo-betonowych. Konf. Konstrukcje Zespolone, Zielona Góra 2011, 125-138.

6. Machelski, C and Toczkiewicz, R 2011. Identification of Connection Flexibility Effects Based on Load Testing of a Steel-Concrete Bridge. Steel Construction Design and Research 1, 58-66.

7. Machelski, C 2011. Siły styczne w podatnym połączeniu elementów zginanych. Inżynieria i Budownictwo 12, 679-683.

8. Machelski, C 2008. Modelowanie konstrukcji gruntowo-powłokowych. Dolnośląskie Wydawnictwo Edukacyjne. Wrocław.

9. Machelski, C 2018. Budowlane obciążenia podatnych obiektów inżynierskich. Construction load of the soil-steel structures. Przeglad Komunikacyjny 10, 30-35.

10. Machelski, C 2014. Zależność deformacji konstrukcji gruntowo-powłokowej od kierunku przejazdu. Drogi i Mosty 13, 223-233.

11. Siwowski, T 2017. Przegląd innowacyjnych materiałów i form konstrukcyjnych w mostownictwie. Mosty 6, 22-27.

12. Siwowski, T, Rajchel, M, Kaleta, D and Włosek, L 2016. Pierwszy w Polsce most drogowy z kompozytów FRP. Inżynieria i Budownictwo $\mathbf{1 0}$.

13. Sobótka, M 2018. Numerical simulation of hysteretic live load effect in soilsteel bridge. Studia Geotechnika et Mechanica 36.1, 103-109. 